\title{
IMPLEMENTASI NAFKAH IDDAH PADA PENGADILAN AGAMA WATAMPONE
}

\author{
Oleh. Nurtasdiq
}

STAI Al-Gazali Bone, Indonesia

email.nurtasdiq90@gmail.com

\section{Article history:}

Received: $20-06-2020$

Revised: $24-06-2020$

Accepted: $26-06-2020$

\begin{abstract}
This research is about the application of iddah income for wives at the Religious Court in Watampone. The main issues regarding the legal status of iddah livelihoods, and how to determine the amount of iddah livelihoods, as well as the efforts of judges in resolving husband's cases refuse to provide iddah livelihoods. This research is a qualitative research with a normative juridical approach and a philosophical approach.

The provision of livelihood in the Qur'an and the Compilation of Islamic Law in Indonesia is obligatory to be given to the wife after divorce, requested or not requested in court, as long as the divorce is not due to the wife's nusyuz. But this is not the case with his practice at the Religious Courts in Watampone. Determination of iddah income at the Religious Court in Watampone still prioritizes the agreement between the husband and wife, if an agreement is not found between them, the Panel of Judges will determine the amount by considering the husband's ability and wife's needs. Regarding the case of the husband refusing to provide iddah, the Panel of Judges took several efforts, but the efforts taken did not have a strong legal basis, even some of the efforts taken were not in accordance with the existing procedural law.
\end{abstract}

Keywords: Implementation; Iddah; Living Rights; Religious Courts.

\section{Abstrak}

Penelitian ini mengenai penerapan nafkah iddah pada Pengadilan Agama Watampone. Pokok permasalahan tentang status hukum nafkah iddah, dan bagaimana cara penentuan jumlah nafkah iddah, serta upaya hakim dalam menyelesaikan perkara suami menolak memberi nafkah iddah. Penelitian ini adalah penelitian kualitatif dengan pendekatan yuridis normatif dan pendekatan filosofis.

Ketentuan nafkah iddah di dalam al-Qur'an dan Kompilasi Hukum Islam di Indonesia adalah wajib diberikan kepada istri yang ditalak raj'i, diminta ataupun tidak diminta dalam persidangan, selama perceraian bukan karena nusyuznya istri. Namun tidak demikian dengan peraktiknya di Pengadilan Agama Watampone. Penentuan nafkah iddah pada Pengadilan Agama Watampone tetap mengedepankan kesepakatan antara pihak suami dan istri, apabila tidak didapati kesepakatan antara keduanya, maka Majelis Hakim yang akan menentukan jumlahnya dengan mempertimbangkan kemampuan suami dan kebutuhan istri. Terkait perkara suami menolak memberi nafkah iddah, Majelis Hakim menempuh 
beberapa upaya, namun upaya yang ditempuh tidak memiliki dasar hukum yang kuat, bahkan beberapa upaya yang ditempuh tidak sesuai dengan hukum acara yang ada.

Kata Kunci: Hak Nafkah; Implementasi; Iddah; Pengadilan Agama.

\section{A. Pendahuluan}

Rumah tangga yang sakinah, mawaddah, warahmah merupakan tujuan perkawinan menurut al-Qur'an. Sejalan dengan itu, dalam Undang-undang Nomor 1 Tahun 1974 Pasal 1 disebutkan bahwa: "Perkawinan ialah ikatan lahir batin antara seorang pria dan seorang wanita sebagai suami istri dengan tujuan membentuk keluarga (rumah tangga) yang bahagia dan kekal berdasarkan Ketuhanan Yang Maha Esa". ' Dalam Kompilasi Hukum Islam (KHI) juga diuraikan pengertian perkawinan sebagai berikut, perkawinan menurut hukum Islam adalah pernikahan, yaitu akad yang sangat kuat atau mitsaaqan galidzan untuk mentaati perintah Allah dan melaksanakannya merupakan ibadah. ${ }^{2}$

Definisi tersebut memberikan penekanan bahwa rumah tangga yang dibangun melalui perkawinan, sangat diharapkan berlangsung lama bahkan kekal. Namun dalam prakteknya, terkadang muncul persoalan-persoalan yang sifatnya memicu percekcokan dalam sebuah rumah tangga, akhirnya berbuah perceraian. Setelah hal itu terjadi, maka wanita diwajibkan atasnya beriddah ketika ia $b a^{\prime} d a$ aldukhul.

Seorang suami yang telah menceraikan istrinya tidak berarti seluruh kewajiban terhadap istrinya gugur secara otomatis, namun seorang suami tetap berkewajiban memberi nafkah kepada istrinya selama menjalani masa iddah dengan cara yang patut. Allah swt. berfirman dalam QS. Al-Ṭalaq/65: 6-7;

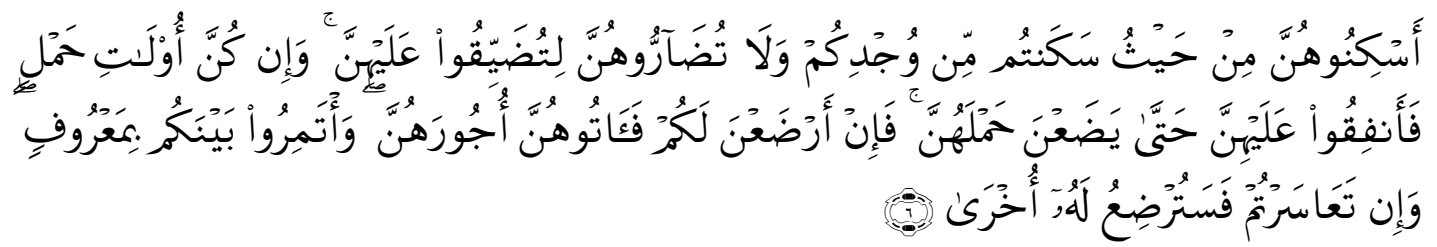

\footnotetext{
h. $1-2$

${ }^{1}$ Redaksi Sinar Grafika, Undang-undang Pokok Perkawinan, (Cet. VI; Jakarta: Sinar Grafika, 2006),

${ }^{2}$ Departemen Agama RI., Kompilasi Hukum Islam, Jakarta: Direktorat Jenderal Pembinaan Kelembagaan Agama Islam Departemen Agama RI., 2000), h. 14
} 
Terjemahnya:Tempatkanlah mereka (para istri) dimana kamu bertempat tinggal menurut kemampuanmu dan janganlah kamu menyusahkan mereka untuk menyempitkan (hati) mereka dan jika mereka (istri-istri yang sudah ditalaq) itu sedang hamil, maka berikanlah kepada mereka nafkahnya hingga mereka bersalin, kemudian jika mereka menyusukan (anak-anak)mu untukmu maka berikanlah kepada mereka upahnya, dan musyawarahkanlah di antara kamu (segala sesuatu) dengan baik, dan jika kamu menemui kesulitan maka perempuan lain boleh menyusukan (anak itu) untuknya. ${ }^{3}$

Perceraian merupakan perkara yang halal tapi dibenci Allah swt. Namun dalam keadaan tertentu justeru perceraian merupakan jalan terbaik yang harus ditempuh oleh pasangan suami-istri, karena sering kali percekcokan yang terjadi sudah tidak bisa diredakan lagi. Ayat tersebut menerangkan tentang kewajiban suami memberi nafkah kepada istrinya selama menjalani masa iddah.

Talak dalam Islam dapat jatuh walau hanya dengan ucapan tanpa melalui proses persidangan terlebih dahulu, ketika seorang suami mengucapkan talak, pada saat itu juga wanita mulai beriddah. Namun saat ini, talak dianggap sah ketika telah melalui proses persidangan. Setelah persidangan selesai, empat belas hari kemudian barulah dapat diterbitkan akta cerai sebagai bukti atau legalitas bahwa seorang wanita telah berubah status menjadi seorang janda.

Setelah seorang wanita berubah status menjadi seorang janda, status tersebut belumlah melekat sepenuhnya, karena ia harus menunggu tiga bulan untuk kepastian statusnya. Apakah ia akan kembali kepada suaminya ataukah benar-benar lepas dari ikatan pernikahan sepenuhnya. Selama menjalani masa iddah tiga bulan lamanya, seorang wanita sebenarnya masih terikat oleh suaminya. Selama tiga bulan itu seorang suami memiliki hak pilih, hak pilih yang dimaksud adalah memilih untuk kembali kepada istrinya ataukah memilih untuk memutuskan ikatan perkawinannya.

Seorang suami memiliki hak pilih, di sisi lain ia juga memiliki tanggung jawab kepada istrinya yang sedang dalam masa menunggu. Kewajiban tersebut adalah berupa sejumlah nafkah yang harus diserahkan kepada istrinya. Penyerahan nafkah ini adalah sebuah kewajiban yang harus dipenuhi oleh seorang suami.

${ }^{3}$ Departemen Agama RI, Al-Qur'an dan Terjemabnya, (Jakarta: Syamil Cipta Media, 2005), h. 559 
Olehnya itu, hal ini harus mendapatkan perhatian yang cukup oleh hukum positif di Indonesia secara umum dan para hakim Pengadilan Agama secara khusus.

Saat nafkah iddah tidak terealisasi dengan semestinya, maka saat itulah ketidak-adilan berlaku, utamanya di mata para wanita yang ditalak oleh suaminya. Ketika ketidak-adilan itu ada, maka hal tersebut sudah sepatutnya untuk dijadikan bahan kajian yang menghasilkan solusi-solusi cemerlang bagi penegak hukum. Melalui pengkajian tersebut, diharapkan terwujudnya keadilan sosial bagi seluruh rakyat Indonesia.

\section{B. Metode Penelitian}

Penelitian ini merupakan penelitian lapangan (field research) dengan jenis penelitian kualitatif. Data diperoleh dari hasil observasi dan wawancara di lapangan, dengan pendekatan yang digunakan adalah teologis normatif, yuridis normatif dan sosiologis. Penelitian ini berlokasi di Pengadilan Agama Kelas I A Watampone. Sumber data berasal dari responden wawancara serta salinan putusan gugatan cerai yang memuat tuntutan nafkah iddah bagi bekas istri yang dibebankan kepada bekas suami oleh pengadilan.

\section{Pembahasan}

1. Status Hukum dan Penentuan Jumlah Nafkah Iddah pada Pengadilan Agama Watampone

Di dalam Kompilasi Hukum Islam Pasal 149 dijelaskan bahwa, bilamana perkawinan putus karena talak, maka bekas suami wajib memberi nafkah, maskan dan kiswah kepada bekas istri selama dalam iddah, kecuali bekas istri telah dijatuhi talak ba'in atau nusyuz dan dalam keadaan tidak hamil. ${ }^{4}$ Jika dicermati kalimatnya, akan ditemukan status hukum yang menunjukkan bahwa nafkah iddah merupakan hal yang wajib untuk ditunaikan. ${ }^{5}$

Untuk itu, apabila seorang istri (sebagai tergugat) menginginkan nafkah iddah dari suaminya selama persidangan berlangsung, maka istri sebagai termohon mengajukan gugatan rekonvensi, dimana dalam gugatan tersebut istri menyertakan

\footnotetext{
${ }^{4}$ Departemen Agama RI, Direktorat Jenderal Pembinaan Kelembagaan Agama Islam, Kompilasi Hukum Islam, (t. t., t. p., 2000), h. 69.

${ }^{5}$ Fatma Novida Matondang, Konsep Nusyuz. Suami dalam Perspektif Hukum Perkawinan Islam”, (Tesis Pascasarjana Universitas Sumatera Utara Medan, 2009), h. 86.
} 
permohonan nafkah iddah. Namun demikian, hal ini belum memberikan kepastian bahwa istri akan mendapatkan nafkah iddah yang diminta. Selanjutnya majelis hakim tetap akan mempertimbangkan keadaan suami. ${ }^{6}$

Kurangnya pengetahuan masyarakat dengan hal tersebut menyebabkan permohonan nafkah iddah sangat jarang dibahas dalam sidang perceraian. Sebagaimana yang diungkapkan Arafah, bahwa selama satu tahun beliau ditugaskan sebagai hakim di Pengadilan Agama Watampone, belum pernah mendapati permohonan nafkah iddah istri yang ceraikan oleh suaminya. Padahal selama satu tahun tersebut, terdapat beberapa perkara cerai talak yang telah dihadapi. $^{7}$

Dengan demikian, amanah agama yang telah dibahas sebelumnya mengenai nafkah iddah, dan amanah negara melalui regulasi aturan yang ada menjadi kurang efektif dalam pelaksanaannya. Banyak istri yang tidak mendapatkan hak nafkah iddahnya karena tidak mencantumkan permohonan dalam gugatan rekonvensinya. Sementara hakim bersifat pasif, yakni hanya memutuskan sesuai dengan perkara yang diajukan.

Di sisi lain, hakim juga dituntut untuk progresif, yakni menemukan hukum baru yang dianggap paling sesuai dengan situasi dan kondisi saat itu. Olehnya itu, ada beberapa hakim dengan ex oficio yang dimilikinya berani membebankan nafkah iddah kepada suami yang ingin menceraikan istrinya, walaupun permohonan nafkah iddah tidak ada dalam materi gugatan. Namun tidak banyak hakim yang melakukan hal ini. Sebagaimana yang dituturkan oleh Makmur:

"Istri tidak menyertakan permohonan nafkah iddah pada gugatan rekonvensi, namun majelis hakim akan mempertimbangkan sebab-sebab perceraian. Sebagai contohnya, awal mula penyebab tidak harmonisnya hubungan rumah tangga sehingga ingin bercerai dikarenakan suami melalaikan tanggung jawabnya sebagai kepala rumah tangga, yakni menafkahi keluarga, padahal ia dalam keadaan mampu untuk menafkahi. Ini didasarkan atas hak ex oficio yang dimiliki oleh hakim".

${ }^{6}$ Makmur, Hakim Pengadilan Agama Kelas I A Watampone, Wawancara, 12 Oktober 2017

${ }^{7}$ Arafah, Hakim Pengadilan Agama Kelas I A Watampone, Wawancara, 12 Oktober 2017

${ }^{8}$ Makmur, Hakim Pengadilan Agama Kelas I A Watampone, Wawancara 12 Oktober 2017 
Selain itu, terdapat juga beberapa keadaan dimana istri memang tidak berhak atas nafkah iddah: Pertama, istri dalam keadaan ghaib. Maksudnya adalah, istri tidak diketahui alamatnya dan tidak pernah memenuhi panggilan selama persidangan. Kedua, istri dalam keadaan nusyuz. Maksudnya adalah, istri diceraikan karena melakukan pembangkangan terhadap suaminya. Hal ini juga dapat menjadi penghalang si istri tidak mendapatkan nafkah iddah.

Bagi istri yang diceraikan dan tidak mengerti tentang nafkah iddah yang seharusnya menjadi haknya dalam iddah, jika ditangani oleh hakim yang kurang progresif, maka terabaikanlah hak istri tersebut. Karena hakim bersifat pasif dan hanya mengadili perkara yang diajukan dalam permohonan/guagatan.

Selain itu mengenai penentuan jumlah nafkah iddah, telah banyak disinggung dalam al-Qur'an, dikaji oleh para ulama dan dituangkan dalam perundang-undangan di Indonesia. Namun tidak demikian mengenai penentuan jumlahnya. Prinsip tentang penentuan jumlah nafkah iddah adalah penyesuaian antara kemampuan suami dan kebutuhan istri. Sebagaimana yang terdapat dalam QS. Al-Talaq/65: 7

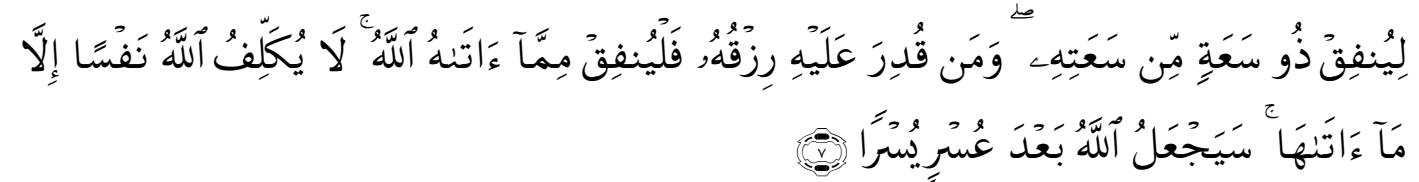

Terjemahnya: Hendaklah orang yang mampu memberi nafkah menurut kemampuannya. dan orang yang disempitkan rezkinya hendaklah memberi nafkah dari harta yang diberikan Allah kepadanya. Allah tidak memikulkan beban kepada seseorang melainkan sekedar apa yang Allah berikan kepadanya. Allah kelak akan memberikan kelapangan sesudah kesempitan. ${ }^{9}$

Beberapa pertimbangan mengenai penentuan jumlah nafkah iddah yakni: Pertama, nafkah iddah diberikan sesuai dengan jumlah yang dicantumkan istri dalam gugatannya, apabila suami menyetujui tuntutan tersebut. Kedua, apabila tidak didapati kesepakatan antara suami dan istri dalam persidangan, maka majelis hakim yang akan menentukan jumlahnya dengan terlebih dahulu melihat kemampuan suami secara rasional. ${ }^{10}$

\footnotetext{
${ }^{9}$ Departemen Agama RI, Al-Qur'an dan Terjemahny,..,.h. 559

${ }^{10}$ Nurmiati, Hakim Pengadilan Agama Kelas I A Watampone, Wawancara 12 Oktober 2017
} 
Adapun yang menjadi pertimbangan hakim dalam menentukan jumlah nafkah iddah yakni: a). Melihat usia suami, dari usia dapat diketahui produktif dan tidak produktifnya seseorang; b). Melihat propertis/kemampuan suami; c). Melihat tingkat kebutuhan primer daerah yang ditempati istri; serta d). Mempertimbangkan tingkat inflasi. ${ }^{11}$

Hal ini sejalan dengan pendapat al-Qurtubi, bahwa firman Allah (لينفق) maksudnya adalah, hendaklah suami memberi nafkah kepada istrinya, atau anaknya yang masih kecil menurut ukuran kemampuan baik yang mempunyai kelapangan atau menurut ukuran miskin andaikata dia adalah orang yang tidak berkecukupan. Jadi ukuran nafkah ditentukan menurut keadaan orang yang memberi nafkah, sedangkan kebutuhan orang yang diberi nafkah ditentukan menurut kebiasaan setempat. $^{12}$

\section{Upaya Pengadilan Agama Watampone dalam Menyelesaikan Perkara}

\section{Suami Menolak Memberikan Nafkah Iddah}

Tujuan pihak-pihak yang berperkara menyelesaikan perkara perdatanya kepada pengadilan adalah untuk menyelesaikan perkara mereka secara tuntas dengan putusan pengadilan. Tetapi adanya putusan pengadilan saja belum berarti sudah menyelesaikan perkara mereka secara tuntas, melainkan jika putusan tersebut telah dilaksanakan, barulah perkara dianggap tuntas. ${ }^{13}$

Tujuan hukum adalah keadilan, kepastian dan kemanfaatan. Putusan hakim wajib untuk dilaksanakan, ketika tidak dilaksanakan maka sama halnya tindakan tersebut merupakan tindakan melawan hukum. Tindakan melawan hukum akan menuai sanksi, diharapkan dari sanksi tersebut dapat memberikan efek jera bagi pelanggar hukum.

Berbeda dengan hukum perdata, khususnya persoalan nafkah iddah. Ketika suami menolak untuk memberi nafkah iddah, maka tidak ada regulasi yang mengatur tentang sanksinya. Dalam hal suami menolak untuk memberikan nafkah

\footnotetext{
${ }^{11}$ Makmur, Hakim Pengadilan Agama Kelas I A Watampone, Wawancara 12 Oktober 2017.

${ }^{12}$ Muhammad al-Qurthubi, Al-Jami' li Ahkam Al-Quran (Beirut: Dar-al-Ihya li Tirkah al-Arabi, 1985), Juz XVIII, h. 170

${ }^{13 R i d w a n}$ Syahrani, Buku Materi Dasar Hukum Acara Perdata, (Bandung: PT. Citra Aditya Bakti, 2004), h.151
} 
iddah kepada istrinya, si istri diperkenankan untuk menempuh satu upaya hukum, yakni permohonan eksekusi. ${ }^{14}$

Permohonan eksekusi ini dimaksudkan agar pihak pengadilan melakukan penyitaan terhadap kekayaan suami. Kemudian dari hasil penyitaan itulah istri diberikan hak nafkah iddahnya. Namun tidak banyak dari pihak istri yang menempuh upaya ini, dikarenakan biaya eksekusi yang tidak sedikit jumlahnya. Jika ini terjadi, maka tidak terpenuhilah tujuan hukum, yakni keadilan, kepastian dan kemanfaatan hukum.

Menurut Nurmiati, Apabila suami menolak untuk memberikan nafkah iddah kepada istri yang telah ia ceraikan, ataupun diragukan ia tidak akan melaksanakan putusan Majelis Hakim, maka akan ditempuh beberapa alternatif sebagai berikut: Pertama, melakukan pendekatan agama. Pihak suami diberikan penjelasan tentang perintah-perintah agama serta hikmah di balik perintah-perintah tersebut. Jika pihak suami masih menjunjung tinggi nilai-nilai agama, maka cara inilah yang paling efesien.

Kedua, mengambil janji dari pihak suami sebelum pengucapan ikrar. Maksudnya adalah, majelis hakim dan pihak suami terlebih dahulu bersepakat tentang jumlah, waktu dan tempat pemberian nafkah iddah tersebut. Hal ini dilakukan jika pihak suami belum mampu menyerahkan nafkah iddah kepada istrinya sesaat sebelum pengucapan ikrar talak.

Ketiga, menahan pengucapan ikrar selambat-lambatnya enam bulan atau menahan akta cerai sebelum penyerahan nafkah iddah. Tapi cara seperti ini tidak pernah dilakukan, karena hal ini tidak sesuai dengan aturan yang ada dan dianggap melanggar hukum acara. ${ }^{15}$

Makmur juga menambahkan, bahwa ketika suami menolak untuk memberikan nafkah iddah, maka majelis hakim memberikan semacam ultimatum dengan dalih: "suami harus memberikan/menyerahkan nafkah iddah sesaat sebelum ikrar". Jika tidak diserahkan maka suami tidak diperbolehkan mengucapkan ikrar selambat-lambatnya enam bulan lamanya. Dalam waktu enam bulan tersebut

\footnotetext{
${ }^{14}$ Nurmiati, Hakim Pengadilan Agama Kelas I A Watampone, Wawancara 12 Oktober 2017.

15Nurmiati, Hakim Pengadilan Agama Kelas I A Watampone, Wawancara 12 Oktober 2017.
} 
Implementasi Nafkah Iddah... $\mid$ Nurtasdiq

ternyata suami tetap tidak menyerahkan nafkah iddah, maka putusan akan dianggap mentah. ${ }^{16}$ Hal ini dilakukan hakim demi kemanfaatan hukum dan menjaga hak-hak istri. Namun demikian tetap saja cara ini memiliki celah karena tidak adanya regulasi yang mengatur. ${ }^{17}$

Olehnya itu, untuk menjaga hak-hak wanita agar mendapatkan keadilan, kemanfaatan terlebih lagi kepastian hukum, maka Makmur mengharapkan agar para akademisi ikut andil dalam memperjuangkannya. Perjuangan yang dimaksud adalah menyertakan dalam tulisannya tentang pentingnya diadakan regulasi.

Regulasi yang diharapkan misalnya: Suami tidak diperkenangkan mengucapkan ikrar talak sebelum menyerahkan nafkah iddah kepada istrinya atau hakim berhak memerintahkan untuk melakukan sita terhadap propertis suami sebagai jaminan, jika dalam persidangan nantinya ternyata suami menolak memberikan nafkah iddah, maka propertis yang disita tersebut akan diberikan kepada istri yang dicerai.

Demikianlah upaya hakim Pengadilan Agama Watampone dalam menyelesaikan perkara suami menolak memberikan nafkah iddah kepada istrinya. Tindakan suami menolak memberikan nafkah iddah merupakan tindakan melawan hukum yang seharusnya mendapatkan sanksi atas pelanggarannya. Namun sayangnya tidak ada regulasi yang dapat dijadikan acuan oleh hakim dalam menangani hal tersebut.

${ }^{16}$ Tidak berkekuatan hukum dan ketika suami ingin mengucapkan ikrar talak, maka harus memasukkan permohonan yang baru.

${ }^{17}$ Makmur, Hakim Pengadilan Agama Kelas I A Watampone, Wawancara 12 Oktober 2017. 


\section{Penutup}

Sebagai kesimpulan dari hasil penelitian, yaitu: Pertama, status hukum nafkah iddah pada Pengadilan Agama Watampone adalah sangat kondisional. Kondisonal yang dimaksud adalah, tergantung pengetahuan istri mengenai nafkah iddah dan usaha istri dalam memperjuangkan hak-haknya. Selain itu, kebijakan majelis hakim juga sangat menentukan berhasil atau tidaknya istri memperoleh hak nafkah iddahnya.

Kedua, penentuan jumlah (kadar) nafkah iddah tidak ditemukan angka yang pasti baik dari teks-teks suci maupun aturan perundang-undangan di Indonesia. Penentuan jumlah (kadar) nafkah iddah pada Pengadilan Agama Watampone meliputi dua keadaan yakni: Nafkah iddah diberikan sesuai dengan jumlah yang dicantumkan istri dalam gugatannya, apabila suami menyetujui tuntutan tersebut, dan apabila tidak didapati kesepakatan antara suami dan istri dalam persidangan, maka majelis hakim yang akan menentukan jumlahnya dengan terlebih dahulu melihat kemampuan suami secara rasional. ${ }^{18}$ Sedang;

Ketiga, mengenai upaya yang ditempuh pengadilan dalam perkara penolakan pembayaran nafkah iddah yaitu: a). Istri diperkenangkan untuk mengajukan permohonan eksekusi; b). Majelis Hakim melakuakan pendekatan agama; c). Majelis Hakim mengambil janji dari pihak suami sebelum pengucapan ikrar; d). Majelis Hakim menahan pengucapan ikrar selambat-lambatnya enam bulan atau menahan akta cerai sebelum penyerahan nafkah iddah.

${ }^{18}$ Nurmiati, Hakim Pengadilan Agama Kelas I A Watampone, Wawancara 12 Oktober 2017. 


\section{DAFTAR PUSTAKA}

Ani Sri Duriyati. Pelaksanaan Putusan Perceraian atas Nafkah Istri dan anak dalam Praktek di Pengadilan Agama Semarang, Tesis Pascasarjana Universitas Diponegoro Semarang, 2009.

Damis, Harijah. Menguak Hak-Hak Wanita, Palopo: Two.F Publisher, 2009.

Departemen Agama RI, Al-Qur'an dan Terjemahnya, Jakarta: Syamil Cipta Media, 2005.

Departemen Agama RI. Kompilasi Hukum Islam, Jakarta: Direktorat Jenderal Pembinaan Kelembagaan Agama Islam Departemen Agama RI. 2000.

Marwing, Anita. Perlindungan Hak-hak Perempuan Pasca Perceraian Studi Terhadap Putusan Pengadilan Agama Palopo, Palita, Vol. 1, No. 1, April 2016.

Matondang, Fatma Novida. Konsep Nusyuz Suami dalam Perspektif Hukum Perkawinan Islam", Tesis Pascasarjana Universitas Sumatera Utara Medan, 2009.

al-Qurthubi, Muhammad. Al-Jami' li Ahkam Al-Quran Beirut: Dar-al-Ihya li Tirkah al-Arabi, 1985. Juz XVIII.

Redaksi Sinar Grafika. Undang-undang Pokok Perkawinan, Cet. VI; Jakarta: Sinar Grafika, 2006.

Ridwan Syahrani, Buku Materi Dasar Hukum Acara Perdata, Bandung: PT. Citra Aditya Bakti, 2004.

Salinan Putusan Perkara Cerai Talak Nomor 143/ Pdt. G / 2015 / PA Wtp. 